\title{
THE BACTERIOLOGY AND PATHOLOGY OF DIPHTHERIA.
}

By Simox FlexNer, M.D.

ASSOCTATE IS PATHOLOGY, JOIISS HOPKINS UNTVERSTY: RESIDEST PATHOLOGIST TO THE JoINS HOFKus MOSPTAL.

The results of the resenrches of Loeffler, puhlished at the close of the year 1883, may he said to mark the heginning of the new era in the study of diphtheria. With these researches closed the epoch which must he considered to have heen inaugurated with the vritings of Bretonneau, which represent the beginning of the scientific history of diphtherin, and to have ended with the cultivation and inoculation experiments of Klehs and his pupil Graham Browa, which led to the discovery although, indeed, not to the isolntion of the specific micronrganisms of the disease. This period included the experimental researches of Hallier, Letzerich, Rosenhach, Wood and Formad, and others. The failure of Klehs to ohtain in pure culture the hacillus diphtherix, which he accurately saw and described in the diphtheritic membrane, illustrates with what difficulties the hacteriologist liad to coutend hefore the introduction hy Koch of the solid culture media.

Whatever douhts surrounded the first publication of Loefler regarding the relation to diphtheria of the micro organism which now hears his name, have nuw heen finally dissipated. The isolation of the Loeffler hacillus, by workers in different parts of the world, from the local lesions of the disease in many thousands of cases would seem to afford irrefutable evidence of the constancy of the relationship existing hetween the hacillus and the pathnlogical process. Hence it is that atteation has heen directed to a consideration of other aspects of the suhject, that of the presence or ahsence of the Loeffier hncillus in primary diphtheria.

The wide divergence of opinions regarding diphtheria which existed prior to the discovery of the bncillus diphtherix illustrates with whit difficulty every advance in the study of a disease is accompanied so long as its etiological factor is unknown. It had long been n well-estahlished fact that hy $n$ variety of agents pseudo-memhranes, which offered more or less the appenrances seen in diphtherin, could be produced upon mucous surfnces in man and in animnls, but it was at the same time recognized that none of these ngents could reproduce the symptom. complex of diphtheria; and none of us is likely to forget the almost interminahle discussion which arose as to whether it was primarily a local or a constitutional disease. Nor did the study of its pathology give much assistance in the solution of this question, and only nfter the

I Read before the Alumnt Asectation or the Jefteren Medical Coltege, Philadelphin, January 8,1805 . 
specific micro-organisms had been ohtained in pure culture did it become possible, hy a study of its properties outside the hody and of its occurrence under natural conditions in human heings, to establish a rational basis for a classification of the disease.

First of all, then, it is important to distinguish hetweeu the nnntomical and the etiological significance of the term "diphtheria," and it will be found that a limitation of the term to a disease characterized hy the presence of the hacillus diphtherise in the affected portions of the hody will do much to eliminate the confusion of pathological conditions which, while anntomically resembling one nnother, are otherwise quite distinct.

I deem it unnecessary to hring hefore you nt this time, in a systematic manner, the hacteriological evidence that the Lneffler bacillus is the sole cause of diphtheria; nor shall I occupy your time witb a description of the hiologic properties of the organism. The cultures which I pass around will show the manner of the growth of the bacillus upon various culture media, and under the microscope cover-slip preparations can be seen which will exbibit to you its cbaracteristic morpbology. I would, howrever, emplinsize the fact tbat the properties of tbe Loeffler bacillus are sufficiently characteristic to permit of its recognition under the most dircrse circumstauces and stamp it as a distinct species.

The first question to wbicb I would direct your attention regards the proportion of cases of pseudo-membranous intlammation of the throat which are due to tbe Loeffler hacillus. In the first series, reported by Loeffler himself, a certain number of tbe cases examined did not yield the dipbtheritic bacillus; but of tbese several were recognized as not having been cases of primary diphtberia. Tbis failure to find the Loefler bacillus in all pseudo-membranous influnmations in the throat - and air-passnges has been confirmed by later investigators. Thus, in a tahle prepured by Esclisrich, in 679 exnminations collected from Paris, Berlin, and New York, tbe bacillus dipltheriæ was found in 427 , or in 62 per cent. of all the cases. In a series studied by Morse, of Boston, of 301 cases exnmined, in 217 was found the Loeffler hneillus-i. e., it was present in 72 per cent. of the cases. Park and Beebe report that of 5611 cases examined, positive results were obtained in 3255 (58 per cent.). The bacillus was ahsent in 1540 cases (27 per cent.), while 816 cases were doultful. The douhtful cases represent those in which for some reason or another satisfuctory cultures were not supplied. If these, then, he disregarded altogether, although it may not be entirely fair to do this, we find that out of 4795 cases of suspected diphtberia, 68 per cent. were instunces of true diphtherin.

It is acknowledged tbat the pseudo-membranous angine which are associated with the ncute exantbemata are commonly not caused by the Lueffler hacillus, but are due, in most cases, to the invasion of the 
streptococcus pyogenes. In a series of bacteriological examinations made by Booker in such cases, the bacillus diphtberixe was constantly absent, and Escberich, who studied fourteen cases of scarlet fever, states that tbe Loeffler bacillus is never present in the early days of tbe disense, but that in several of these cases it was found to be present later on, a fact whicb he attributes to the imperfect separatiou of dipbtberia and scarlet fever patients in the Munich Hospital, where his studics were carried out. He also fou od the Loefler bacillus in certain cases of measles and whooping cougb, and he agrees witb other investigntors in boldiog that the acute exantbematous diseases predispose to infectioo witb the bacillus diphtberise.

It bad heen observed by the older clinicians that during epidemica of diphtberia pseudo-membruoous inflammations of tbe tbroat, in the course of typhoid fever, were more frequent. Morse reports four cases of typhoid ferer complicated witb diphtberia, of which at least tbree developed diphtlieria after udmission to the hospital.

A purely local and perhaps non-contagious inflammation of the larynx has, by the bacteriological examination of a considernhle number of cases of membrnoous croup, been shown to oceur unassociated with diphtberia. These cases, howrever, are quite exceptional. Of 88 cases of memhranous croup studied hy Mfnrtin, 59, or 67 per cent., were of diphtheritic origin. The statistics of Park indicute thut in New York fully 80 per cent. of the cases of the sarie disease are caused by the Loeffler hucillus. Of 229 of Park's cases, in 167 no memhrane or exudate was found above the larynx. Welch and Abbott, Booker, Willinms, Kalisko and Paltuuf, Cuncietti nud Frnenkel have reported cases of Inryngeal diphtheria in which the pseudo-menuluave was confined to the laryn $x$ and lower air-passages.

The rare and interesting case of ascending croup, in which the memhrane hegins in the deeper portions of the air passuges and extends upward, have heen little studied. From the lungs of one sucb case Martin cultivated the Loeffler hucillus in large numbers.

It is an undoubted fact tbat a case of so-called membranous laryngitis has not infrequently been the first of a series of cases of genuine faucial diphtberir.

Among the most important results of the bacteriological study of the inflammations of the throat and air-passages has been the discovery tbat cases wbich present the features of a mild catarrbal angina or of a lacunar tonsillitis may he associated with the presence of the bacillus dipbtberix, and tbat from these can arise other cases in which membrane is found on the fauces. This class of cases has been studied by Escherich and Feer, and especially hy Koplik. Within the past few weeks I have seen two such instances in the practice of Dr. WV. D. Booker, and from them obtained the Loeftler hacilli in cultures. The first was a girl of 
sixteen years, who came to the surgical dispensary of the Johns Hopkins Hospital for enlarged glands of the neck. Upon examination she was found to have a lacunar tonsillitis. She suffered no inconvenience other than that resulting from the swollen glands. The plugs from the crypts of the tonsils contained the Loeffler bacillus. She made a rapid recovery.

The second was a child one and a half years of nge, whose tonsils were greatly swollen and almost meetiug in the middle line of the throat. There was no visible memhrane. Cultures from the throat showed the presence of the bacillus diphtherise. The local trentment recommended by Loeffler was used, and by the third day nll symptoms of the disease had disappeared.

Heubner has just published a short series of cases, in which be calls attention to what he describes under the title of latent diphtheria. These were secondary to other diseases thnu scarlet fever and measles, and occurred in the young in the course of rasting affections, sucb as rickets, tuberculosis, etc., in hospital practice. The symptoms were fever, gastro.jatestinal disturbances, and slight bronchial and nasal catarrb. Heubner says that dipbtheritic infectiou is not apt to be suspected in these cases until laryageal stenosis suddealy develops or the fact is revealed at autopsy by the finding of a false membrane in the pbaryns or larynx.

Roux and Martin have found in the course of tbeir inoculation experiments for the preparation of the antitoxia tbat animis which bad been previously inoculated with otber bacteria or tbeir poisons, from which tbey bad recovered, were more susceptible to the diphtheria toxin; and, similarly, that pregannt animals or such as bad just given birtb to young, exhibited a similar diminution of resistance.

The mucous membrane of the nose affords $n$ favorite resting place for the Loeffler bacillus. In phargngeal dipbtberia tbese bacilli are commonly present in the nasal secretions, even in the abseace of membrane in the nose. Primary diphtleeria of the nasal mucous membrane sometimes occurs. ,First observed hy Baginsky, aỏditional iastances have been reported hy Abhott, Abel, Ravenel, Czemetschka, and Felsenthal. Townsend reports 5 and Park 10 cases of fibriaous rhinitis, in which the membrane was confined to the nose in 4 nnd 9 cases respectively. Katz has just recorded an instance of faucial diphtheria, the infection in which was traced to a case of diphtheritic fibrinous rhinitis. Similar results bave attended the hacteriological examination of other investigators, and Escherich has seen one case in which the infection of the nasal mucous membrane took place tbrough the tear duct ia a case of diphtheritic conjunctivitis.

Babes first cultivated the Loeffler hacillus from the pseudo-memhrane in diphtheritic conjunctivitis, and reproduced the disease by the inoculation of the organism upon the conjunctiva of rabhits. A number of 
eases of pseudo-memhranous conjunctivitis hnve since heen found to he associnted with the bacillus diphtheriz, although it must he stated that not all nre caused hy this organism. In two cases which I exnmined for Dr. Hiram Woods the Loeffler hacillus was not found in the exudate, hut streptococci were present in hoth. 'The results of Councilmnn's investigations would go to show that certain cases of otitis media nre due to the hacillus diphtherix. Fe found this organism in the pus from the middle ear of a patient who had diphtherin, nnd in two cases in measles without diphtheria of the thront.

The skin surfaces of the hody would appear to he immune to the nction of the Loefller bncillus in the absence of nny loss of continuity. Thus Wright cultivated the diphtheria hncillus from excoriated or ulcerated surfaces of the skin in seven cases of diphtheria; and Park found this organism in wounds of the finger received by physicians while performing intubntion. Cases of wound diphtberin associated witb the Loefler hacillus nre reported by Neisser, Treitel, nnd Ahel; hut it is prohahle thnt most cases of so ealled wound diphtherin nre caused by other micro.organisms. The relntive iususceptihility of the externnl surfaces of the body to infection witb the bncillus dipbtherix is illustrated by the belinvior of tracheotony wounds, wbich only exceptionnlly become infected with tbis organism. Foltanek examined 953 trncbeotomy wounds without succeeding in a single instance in isolnting the Loeffler bacillus. Other observers hnve been more successful, but in these cases the possibility of the contaminntion of the wounded surfnces with tbe tracbeal secretion cnnnot he excluded.

. Having now prssed in rapid review the situntions of common localization of tbe Loeffler bncillus upon the surfnce nnd in the cavities of the body, I would ask your nttention to its distrihution within the viscera. At the time of Loeffler's first publication he expressed a helief thnt the bacillus diphtberix was to he found only nt the local site of the disease, nnd that it did not insnde the tissues nt all, or at least only exceptionally. He lund cultivated it, however, in one case from the lungs, nnd later Kolisko nnd Paltauf and Bnbes isolated in rare instances $n$ fer organisms from the internal organs. The observations of Frosch, since confirmed by others, have shown that not uncommonly $n$ few hacilli enter the circulation nnd $m n y$ be cultivated from the internal organs at nutopsy. They are not, however, only small in number, hut their distrihution is irregulnr, nnd it is necessnry to transplnnt considerahle quantities of mnterial in order to grow them. Frosch cultivated the hncillus from the blood of the heart, the hrain, pleurnl nnd pericardinl exudntes, pneumonic areas in the lungs, spleen, kidneys, bronchinl and cervical lymph glands, nnd liver. Booker has also obtained the organism from the iuternnl organs. At tbe nutopsy of a child of three years, which had hoth pharyngeal and laryngenl diphtherin, I ohtained the bacilli 
diphtherix in pure culture from the beart'a blood, cervical lymph glands, liver, spleen, lungs, nnd kidneys; hnt, contrary to Frosch's experience, they were present, in this case, in large numbers in the hlood, glands, and spleen. In this, as well $n s$ in $n$ later instance, I was ahle to cultivate the Loefller hacilli from hroncho-pneumonic nreas, and also to demonstrnte them in sections from the bronchi and lung tissue. The predominating organism, however, was the micrococcus lanceolatus. Kutscher has just shown that the Loefler hscillus exists at times in considerahle numbers and may be the predominating organism in cases of hroncho-pneumonia nssociated with diphtherin, nod he inclines to the view that it is capahle of causing hoth hronchitis and consolidation of the lung substance. Wright has found the hncillus diphtherix in the internal organs in cases of human diphtherin, and he has also cultivated them from the liver, spleen, heart's blood, and kidaeys, in $n$ small number of experimental guiaea pigs. Abhott and Ghriskey found that after inoculating cultures of diphtheria hacilli into the testicle of guinenpigs small nodules contnining this organism sometimes appeared in the omentuum, and this bacillus has ulso been cultivated from the ecchymotic patches ia the stomach and from the surface of the memhrane in croupous gastritis. Of special interest is the case reported by Howard, in wbicb a bacillus in nll respects resembling the bacillus dipbtherix, except that it did not possess patbogenic powers for guinea-pigs, was cultivated in large numbers from the beart valves in a case of ncute ulcerative eadocarditis, nud from the infurctions in the spleen and kidneys.

Notwitbstandiag the results of later and more searching studies whicb hnve necessitated a modification of the earlier views regarding the relation of the Loeffler bacillus to diphtherin, and notwithstanding the fact that it is now known thut the Loeffler hacillus can develop not only locully upon the nflected mucous membrane, it must be considered ns proven that only a few orgnnisins penetrate into the hody; and there are undoubted instances in which the discase has pursued a typical, severe, and even fatal course in which the bacilli have remained localized in the mucous membrane. Hence the local process is still to be regarded as the chief seat of the nctivity of the bacillus diphtherix.

The study of the properties of this hacillus as it exists outside the human body, and the results derived from the inoculation of susceptihle animals, would indicate thnt the effects which it produces upon the hody are due to $\mathbf{n}$ soluhle poison, $\mathrm{n}$ toxin, proceeding from its growth nnd multiplication. By means of this toxin, separated from the living bacilli, all the constitutional effects of diphtheria can be induced. For the production of the false memhrnne the presence of the hacillus itself is necessary.

The growth and multiplication of the hacilli in the false memhrane 
in the pharynx, larynx, and nose are associated with the formation of this toxin, which entering the body causes the symptom-complex of the disease. Sidney Martin has extracted from the pseudo-memhrane an alhumose which possesses the poisonous properties of the toxin.

We owe especially to Roux and Yersin, and Brieger and Fraenkel, our knowledge of the nature and properties of this toxin. According to their researches, it helongs to a class of suhstances of alhuminous nature, possessing poisonous properties, for which the name tox-alhumins has heen proposed. Up to the present time the tox-alhumin of diphtheria has not heen ohtained in a pure form, hut in its impure state it is found to possess extraordinary potency. Susceptihle animals (rahhits, guinea-pigs, bittens) inoculated with it exhihit all the symptoms of diphtheria, not excepting the post-diphtheritic paralysis.

The study of the action of this hacillus upon animals has shown a material difference in the virulence exhibited by cultures derived from different colonies. The guinen-pig, being the unimal most susceptihle to its influence, is generally employed for testing these variations.

A small dose of a virulent culture introduced subcutaneously will kill a guinea-pig in from forty-eight to seventy two hours, and an equal quantity of a somewhat less powerful culture will cause death in from four to six days. The animals show at the seat of inoculation a local memhrane which contains the hacilli nnd a more or less widely sprendiog cedema of the suhcutaneous tissue. The bacilli can he recosered from the seat of inoculation. Weaker cultures may take one, two, or three weeks to bring ahout a fatal result, and there are still others which produce only a local reaction at the points of inoculation, from which the animal recuvers. Different colonies of bacilli ohtained from one case may exhihit these wide variations in virulence.

No less striking are the differences in the potency of the toxin produced hy the hacillus, and it has heen found that there exists a direct relation hetween the virulence of the organism and the intensity of the poison which it is enpahle of yielding.

It cannot be said that any such relation hetween the virulence of the organism and the severity of the symptoms has heen shown to exist for human heings. Indeed, contrary to the results arrived at hy Roux and Yersin, which seemed to iodicate that a progressive diminution in the virulence of the hacilli corresponding with the mildness of the attack took place, and that the same thing happened during convalescence from a severe attack. Escherich, Tohiesen, nnd especially Wright, have shown that no such diminution of virulence occurs. Fully as virulent organisms may he found in cases which are mild from a clinical standpoint as in those of severer grade.

The questions of individual predisposition or of resistance to the invasion of the hacillus diphtherix and to the effects of its toxic products 
have therefore to he considered in this as in the case of other infectious diseases. What the physical hasis for this distinction really is we are prohahly still far from hnving discovered. A few of the conditions which favor or inhihit iufection in human heings and in auimals seem clear. Heuce it is that the results of the recent studies of Wasserman and Ahel upon the action of the hlood-serum of healthy human heings upon animals previously inoculated with the Luefiler hacillus are suggestive, as they indicate that the serum of certain individuals contains some protecting substance, the power possessed hy the serum of adults heing greater than that of children.

It is quite estahlished tbat the bacillus diphtberise may possess all grades of virulence down to complete absence of pathogenic power, and some confusion bas arisen hy the iutroduction of the term "pseudodiphtheritic" hacillus to denouinate an organism which, while it resemhles the true bacillus diphtherix, is devoid of virulence for guineapigs. This hacillus was first isolated hy Hoffmann, who regarded it as identical with Loeffler's hacillus. Roux and Yersin udvanced tbe view that this so.called "pseudo-dipbtberitic" hacillus represents an attenuated form of the truc bacillus diphtheris, and the work of Ahbott, Park, Koplik, and Escherich lend support to this position. On tbe other linnd, it is suggested tliat the nante "pseudo-dipbtberitic" sbould he reserved to designate bacilli which, though resemhling the true dipbtheritio bucillus, sbow certain cultural differences and are devoid of patbogenic effect for guinea-pigs. Such a pseudo dipbtbcritic bacillus has been found in a few cases of genuine dipbtheria associated witl the true hacillus dipbtberix.

It must he confessed tbat our knowledge of the relation of the Loeffler bacillus to dipbtheria and associated pathological processes bas been much extended in the past fow years. Thus tbis organism bas been found in a large proportion of all cases of pseudo-membranous inflammation of the throat, and is the probuble causative agent in all cuses of truc diphtberia. Those pseudo-memhranous anginx in whicb the Loeffler bacillus is not found are characterized in thenselves and distinguished from cases of true diphtheria hy the milduess of their course, their slightly contagious character, and their low mortality; in Park's statistics, excludiug those associated with scarlet ferer, the death-rate was 1.7 per cent.

That virulent diphtheria hacilli may be present upon the mucous memhrane of the pharynx without giving rise to false memhrane is proved hy those cases of pure laryngeal diphtheria from which the hacilli have heen cultivated from the pharyax. Loeffler found in the throat of a healthy child a hacillus which was identical with the true bacillus dipltherix; later Hoffnann, Fraenkel, and Feer found it under similar circumstances. In 330 healthy persoas examined by Park and 
Beehe, who gave no history of contact with diphtheria, they found the non-virulent organisms in twenty-four, virulent hacilli in eight, and pseudo-diphtheritic hacilli in twenty-seven. The examination included for the most part children. Of the eight cases in which virulent hacilli were found, five were children in an asylum where from time to time true diphtheria occurred. Of the remaining three, one was from a house where a supposed case of croup had existed three weeks beforc. Two of the eight children developed diphtheria some days later; the other six remained healthy. Loeffler recently examined the thronts of sixty gchool-children, nnd found diphtheria hacilli iu four. Of these, two suhsequently developed diphtheria, one a slight inflammation of the throat, the fourth remnining well.

The study hy Park of the throats of persons exposed to diphtheria has shown that in 50 per cent. virulent Loeffer's hacilli are present. Of these, 40 per cent. developed later the lesions of the disense. Park states that in the families from which his statistics covering this point were obtained the conditions for the transmission of the disense were most furorable. On the other hand, in families where the patient suffering from diphtheria bad been well isolated, the bacilli were found in less than 10 per cent. of the healtby children.

"Considered in the light of our present knowledge of the common existence of pathogenic micro organisms, such as streptococci, staphylococci, and paeumococci, in the mouths of healthy persons, without necessarily doiag harm there, these facts of the occasional occurrence of virulent dipbtheria bacilli in the throats of healtby persons are less surprising. Doubtless it is necessary that a certain susceptihility to their action, a predisposition, if yon prefer, must exist, hefore their peculiar effects can he exerted. I beg to recall in this place the experi. montal results ohtained from healthy humnn hlood serum as hearing upon this point. However, the figures furnished by Park and Loefler would indicate that the presence of the hacillus diphtherixe in the throat is far more signiticant even for the individunl himself, to leave out of consideration for a moment those with whom he may come in contnct, than are the other pathogenic organisms mentioned.

The hacteriological study of convalescent cases shows tbat virulent hacilli may persist for a time after the disappearance of the false memhrnne. They are not uncommonly present nfter two to three weeks, and in a few instances they have heen found after a much longer period. In a case reported hy Park and one nlso hy Ahel they were still demonstrahle on the fifty-sixth and sixty-finh day respectively after the memhrane had entirely gone.

The severity of the case has no influence upon the duration of the presence of the hncilli; the occnrrence of nasal diphtherin as $n$ complication seems to favor this persistence. Tezenas found in twelve cases 
complicated with nasal diphtheria that for a long time after the memhrane had disappeared a serous exudation from the nose contiaued. In tea of these cases Ioeffler bacilli were demonstrahle so long as the secretion persisted, although they had long ceased to be present in the throat. Hence, where cultures cana ot be made it is recommended to continue the isolation of the patients for at least three weeks after the disappearance of the memhrane.

It is prohahle that the bacillus diphtherim is capahle of increasing only withia the hody of infected persons or in the sent of inoculation of susceptible animals. The bacilli are, however, ahle to remain alive and in a condition capahle of causing iafection for $\mathbf{n}$ coasiderable time when outside the hody. Conditioas which promote the drying of the organism and exposure to strong light are unfavorahle for the preservation of its vitality. The iadividual Loeffer bacilli quickly die when allowed to become air-dry. But in hits of mucus or membrane, particularly if protected from the light and preserved in $n$ damp place, they may remain alive for a long time-upon old cultures from five to fifteen months; in hits of membrane from four to seventeen weeks. They have been cultivated from tahleware and toy3; from soiled liben which had heen in contact with tbe sick ; from the shoes and hair of nurses, and from the broom used to sweep the floor of a diphtheris ward. In view of these facts it is unnecessary to point out the importance of thorough disinfection and of the rigorous care that should he observed in disposing of the excreta of the sick.

Tbe so-called diphtheritic nffections of domestic animals are, perhaps, a ot to he feared as a source of infection for human beings, as the same micro organism is not concerned in their causation. It is, however, not excluded that domestic animals may carry the infection of true diphtheria from one place to anotber, without themselves exhibiting symp. toms of the disesse. At the present time it is not possible to make any positive statements regarding the diphtheria of cats.

The association of other micro-organisms with the bacillus diph therie in the false membrane is by no means uncommon, although cases of pure diphtheritic pseudo-membranous inflammation are known to exist. The organisms usually associated with the Loeffler hacillus are the pyogenic cocci, strepto-, staphylo- and diplococci. Their presence is now kaown to he of great cliaical and pathological significance, especially if they eater the deeper tissues as they are vont to do. While the hacillus diphtherise is found only exceptionally in the adjacent lymph-glands and iuternal orgaas, there exists a group of cases of poly-infection, especially with streptocucci, in which the Jatter enter the circulation and invade the organs. Since the introduction of the antitoxin.treatmeat of dipbtheria this class of cases has nttracted especial atteation.

These cases had been recognized and studied hy a number of ia vesti- 
gators, and in tbis country especially by Councilman and bis associates. Broncbo-pneumonia, suppuration nf lymph glands, and septic forms of dipbtberia are attributed to tbese associafed bacterin, particularly to the streptococcus. Roux and Yersin first pointed nut the importance of this poly-infection, and suhsequently Schreider, Mya, Barbier, and Martin confirmed tbeir observatinns. Funk, Roux nad Martin, and Bernheim hnve recently made careful experimental studies on this subject. Tbe latter employed only nrganisms wbich bad heen associated in the dipbtberitic membrane, and be found that the virulence of the Loeffler hacillus is increased hoth hy heing grown witb tbe streptococcus and in the filtrate obtained from streptococcus cultures. A limited number of experiments witb stapbylococci did not sbow a similar increase - in tbe virulence of tbe hacilus dipbtberix, a result confirmatory of Mya's earlier experiments. On the otber band, in buman beings, according to Morse's statistics, cases of poly-infection with staphylococci run a more unfavorahle course than those with streptococci. Welch has criticised bis conclusions and sbnwa the improbability of their correctness.

I am ndmonished hy the little time which remning to me to he hrief, and all the more hecause the Association is to have from another source a paper oa the antitoxin-treatment of diphtheria. The great ceatral point toward wbich the previous work outlined in this paper all tends has heen the discovery of a rational aad successful tberapy. The culmination seems near at hand.

The natural variation in virulence of the hacillus diphtheriz led first uaiatentionally, and later purposely, to the rendering of animals immune to subsequent inoculation witb the Loefller bacillus. But it was soon ohserved that this metbod of securing immunity was capricious and unreliahle. The use of cultures of hacilli attenuated by cbemical agents, tbe injection of tissue fluids nf an animal dead of $\mathrm{a}$ previous inoculation of the hacilli iato annther, the employment of sterilized houillon cultures and of cultnres grown in in fusions of cellular organs, sucb as the tbymus gland, wbile attended witb success in some cases, were fou ud to be precarious methnds of securing immunity, and not at all ndnpted to large animals. The use of a virus ohtained from houillon cultures several weeks old hy filtration has heen successfully employed by Bebring Ebrlich and Wassermnnn, Roux, and others, to render even large animals, such as the horbe, immune to large doses of diptberia cultures. And one of the surprising and significant facts wbicb have resulted from the study of the changes induced in tbe hody fluids of tbe immune animal consists in the discovery tbat they contain a substance wbich is capable of rendering nther animals and even buman heings immune from dipbtheria and also nf curing the disease after its development. 
This nntitoxia ohtained from the blood of immune naimals, though antidotal to the poison of the bacillus dijhtherix, exerts ao power over the poison produced hy the hacteria associated with the Loeffler hacillus in the pseudo-memhrane, and thus it hecomes clear why cases of polyiafection are less influeaced hy the natitoxin-treatmeat than those of pure diphtheria.

It is hut a confirmation of an intuitive helief to fiad that in the blood of huma heings well of diphtheria there exists a hody similar to that found in immuae animals. The experiments of Klemeucisicz and Esclierich provel the correctaess of this supposition, aad Ahel has just furnished a larger series of ohservations with confirmatory results. In animals a certaia time elapses after the inoculation of the toxin hefore thc antitoxia appears, and it is only after repeated doses at iatervals that a high grade of antitoxic power is developed in the hlood-serum. In humaa heiags the hlood takea on the fifth or sixth day after infectioa shows no protective actioa, the protective power appears from the eighth to the eleventh day, aad it persists $n$ variahle time. Sometimes it fails to appear at all. After some woaths it may he still present, though iu a diminished degree, or it may have entirely disappeared. The loagest periods of persisteace yet ohserved a re oae huadred aad fify and two hundred days.

These facts hear out the experiencc of physicians who have noted that diphtheria is not one of those disenses one attack of which affords protectioa from suhsequeat iafectioa. . Perhaps the iadividual difiereaces ohserved are to he explaiaed hy the vnriatioa ia the amouat of healing and protectiag substance formed in any case.

The time which I have consumed ia dealiag with the hacteriological aspects of my subject leave ine little opportnaity to treat of the path. ology of diphtheria. I shall not weary you with a miaute nccouat of the pathological changes which are found ia this disease. With the appearance of the pseudo-membraae you nre all familiar, and I have already poiated out that in many atypical cases only a hacteriological study can decide the true nature of the case. Ia a case of genuine diphtheria the Loeffler bacilli are found ia great numbers in the pseudomemhrane, there beiag less in the deeper than in the older and more superficial parts; they are also found on the adjaceat mucous memhrane. A lesion of the surface provides $n$ condition favorahle to their settlemeat and iacrease, a fact nlso horne out hy experimeats on susceptille animals. Where no previous defect exists it is prohahle that the toxia itself can cause n superficial lesioa. The toasils, which are the starting-points of many cases of dipht heria, afford aa excellent nidus for the hacilli on accouat of the incompleteness of their epithelial coveriag evea ia health. The depth and extent of the necrosis of the mucous membrane vary in different cases, nad the character of the psendo- 
memhrane is affected hy the nature of the nnderlying structures; in the pharynx it is firmer and less ersily separahle than in the larynx and trachea, where $\mathbf{n}$ distinct hasement memhrane is found ia the mucosa.

The earlier workers in the feld of experimental diphtheria failed to find in the internal organs the lesions which had heen described hy Oertel in the tissues in human heings dead of diphtheria. These lesions consist of foci of cell desth characterized hy extensive destruction and fragmentation of cell nuclei. In such areas of necrosis fihrin may he deposited. Dr. Welch nnd I confirmed and extended these results of Oertel hy experiments upon guinea-pigs, kittens, and rabhits. Suhcutaneous inoculation of the cultures of the nrganism $n r$ of the filtrato of $n$ houillon culture four or five weeks nld produces, hesides the local lesions peculiar to ench, foci of cell death in the adjacent lymph glands and in the lymph glands throughout the hody, in the spleen, liver, lungs, heart, muscle, and intestinal mucosa. The kidneys show degenerative changes. When the dose is small and the animal lives several weeks the paralysis which helongs to the disease may develop. This phenomenon, first observed in animals hy Roux and Yersin, was noticed among our animals. Interesting changes have been described in the peripheral nerves under these conditions hy Sidney Martin. In some cases he observed defects in the myeline shenths, which stained poorly in osmic acid, while in certain severe cases the sheaths had entircly disappeared. The nxis.cylinders wcre either intact or had undergone granular degeneration and the continuity of some of the fibres liad become broken. At times the muscles supplied hy these nerves showed signs of fintty degeneration. These changes agree with those found hy Gomhault Meyer, Ireyden, and Arnheim in human heings who bad suffered from diphtheritic paralysis.

According to Johannessen ${ }_{3}^{1}$ post-diphtheritic paralysis develops in human beings in cases which hnve pursued n mild course apparently, as well as in those of severer grade. The percentage, however, is higher in epidemics which have heen of a severe character; the figures given hy Unterholzner heing 4 and 17 per cent. respectively. G. Hoppe-Seyler found that paralysis developed in 27 per cent. of cured cases. MendeI has called attention to the common ahsence of the knee-reflex nfter diphtheria, which may not return fnr five to sis months, and of great interest are those instances in which five to six weeks after the disease paralysis of the diaphragm intervenes in which a mortality of 50 per cent. has heen ohserved.

Alhuminuria is a not iafrequent complication of the disease. Thom-

1 Fnt the statistics nf the frequeney nf the afeclunn nf rarinus nrgans in human diphtheria I nm Indebted tn the recent puper by Seitz entitled Dle Fnrtschritte unserer Kenntnisse über Unsuche. Wesen u. Belitaprung der Diptherie in letaten Deeennitum. Muyehener med. Wochenschrift, I894, Nos, 50 and 52. 
sen states that it occurred in 21 per cent. of his cases; and Baginsky and Jansen, in hoth of whose cases the hacteriological diagnosis was made, found it in 46 per cent. of theirs. The figures given hy others are: G. Hoppe-Seyler, 61 per cent.; Cadet and Gassicourt, 75 per cent.; Ranke: 85 per cent.; nnd Unruh, 100 per cent. Hsgenhach states that of all cases which come to nutopsy 34.6 per cent. show kidney lesions; and Schrakamp found nephritis in 40 per cent, and Cropf in 46.2 per cent. of such cases. In twenty-four cases in which the hacteriological diagnosis had been mnde, Felsenthnl and Bernhard found at autopsy thnt the cortex of the kidneys was increased, and that the epitbelium of the tulules was swollen, vacuolated, necrotic, and disintegrating. The morphological constituents of the urine vary with the symptoms, and, depending upon these, hyaline, epithelial, and fatty-granular casts mny be present. In severe cases the urine may he much diminished in amount; hut uremia is unusnal, and hydrops, which seldom occurs, is, when present, of a mild grade.

The heart is not uncommonly involved. The affection is, bowever, usually not of its serous coats, nlthough perienrditis nnd endocarditis nre known to occur. But it is the muscular structure which suffers, nnd perhnps the aervous mechanism as well. The figures indicatiag the percentage of cases in which the heart is affected in the couree of diphtherin vary from 10 per cent. to 38 per cent. (G. Hoppe Seyler). The histo. logicnl chnnges are described as heing either of the parenchymntous variety, in severe grades associated with fntty degeneration, or as coasisting of an interstitinl myocarditis.

The lymphntic glands of the neck, which usually become surollen, show only a slight tendency to suppuration; necording to Heaoch, suppuration occurs in 2 per ceat. of the cases. The spleen is commonly eaougb somewhat enlnrged, hut it is only exceptionnlly found to rench a considerahle size. Various complications may develop in the course of the disease, the most frequent beiag pneumonia; hut this is due in the great nrajority of instances, as douhtless are nlso the joiut nffectioas which oceur, to the invasion of secondary micro-organisms.

In conclusion, I have in this paper attempted to show, although necessarily in an incomplete and fragmentary manncr, that in the last decade, hy the employment of modern methods of research, more light has hcen thrown upon diphtheria than had been gained in the half century which hnd elapsed since its description hy Bretonneau, and I think thnt I may snfely say that there is no other infectious disease which has heen rendered so clear in its etiology and pnthology, so amenahle to prophylaxis, nnd in the treatment of which so much is now promised. 